\title{
A Word from a Founder, to Those Who Follow
}

Gerrit Olivier (Extraordinary Professor, Dept of Political Sciences, University of Pretoria)

It is indeed gratifying to witness the fruits of the initiative of a small group of political scientists assembling at Pretoria University forty years ago to establish the South African Political Science Association (SAPSA) with Politikon as its flagship journal. From this inauspicious beginning, both SAPSA and Politikon have developed into becoming success stories, being recognised, both nationally and internationally, as the main and representative fora of South African Political Scientists.

As founder member of SAPSA and first editor of Politikon it gives me great pleasure indeed to thank and congratulate everybody who has participated in and contributed to this long building process to achieving the successes of the past forty years. At the same time, also my appreciation to the editors, Peter Vale and Pieter Fourie, and also the Editorial Board, for producing this special Anniversary edition of Politikon, as well as to all the contributing authors for the rich variety of articles they prepared to make this a very special issue. No doubt a splendid testimony to the growth, development and vibrant health of our discipline after four decades. In his chapter Peter introduces these contributions, and what is left to me is to write this brief introductory piece. With the benefit of forty years hindsight some personal reminisences and a few observations about the launching of Politikon the teaching and societal impact of political science and international relations in South Africa are perhaps appropriate. At the same time, as first editor, I also want to express my appreciation for being invited to write something by way of introduction. I had never expected, not even in my wildest imagination, when all started from scratch four decades ago, that I would one day have the pleasure of witnessing so much fruit on our labour and be honoured with this invitation.

As I said, our genesis was inconspicuos and uncertain of success. At the time of the establishment of SAPSA (now South African Association of Political Science (SAAPS)) and Politikon, universities in South Africa existed almost like isolated islands, rarely interacting or cooperating. No doubt, the deeply divided nature of the apartheid state and society impacted profoundly on academic scholarship in the country with the result that cooperation among political scientists until the early 1990s was at best sporadic, if not utterly constrained. However, what the founding members realised right from the outset was that any effort which was not per definition national and inclusive, not reaching out to the entire school of political scientists, would be short-lived, if not a wasted effort. Inclusiveness, serving the discipline accross all boundaries was, therefore, our lode star right from the beginning. Following this objective, the editorial policy of Politikon was similarly to supply a legitimate and representative forum for the entire spectrum of political science practitioners, to be politically/ideologically neutral, publishing articles on the basis of their scientific-scholarly merit alone. Initially, for me as editor, involving colleagues at English language universities was not an easy task. However, and fortunately so, this changed over time as participation and membership SAPSA grew to becoming more representative. To-day, some forty years later, this objective has been fully achieved. No doubt, something to be proud of.

During Politikon's forty years' existence major events and profound changes have taken place on the political scene, both at home and abroad. For South Africans, most important among these was, no 
doubt, the end of apartheid, a truly liberating experience, leading to a profound renewal in the way political science and international politics were being taught and practised as academic disciplines in South Africa. It allowed the local academic fratenity to break out at last from the restrictive parochial environment becoming unfettered and free to reach out to becoming part of a wider,universal environment.

A important point to make here is, however, that the breakdown of international academic contact isolation during the apartheid years was never absolute as the 'South African question' interested and involved various international scholars of high standing and provoced an intense debate. All these people opposed the apartheid system in no uncertain terms, but at the same time, they cared greatly about South Africa being blighted by this policy, and their intellectual contributions, no doubt, helped greatly to clarify some of the crucial issues which faced the country. Names which come to mind here are Arend Lijphart, Samuel Huntington, Roger Fisher, David Easton, Vernon van Dyke, Charles Manning, Ned Munger, Theodor Hanf, James Barber, Jack Spence, Tom Karis, Gwendolene Carter, Russsell Kirk, Ned Munger,Calvin Woodward and Merle Lipton. They participated and enriched the 'Great Debate' about where the country was headed while also stimulating thinking and research by interacting with local political scientists and public role players. Some of them also addressed SAPSA conferences as key note speakers and also made valuable contributions to Politikon.

In his contribution, an eclectic overview of the study of politics in South Africa, Peter Vale looks at the role played by notable South African political scientists over the years as well as the state of the discipline. This presents a lattice-work scenario predicated mostly on normative assumptions and/or preferences, including advocacy, relating to politics and political thinking in South Africa over the years. From my own experience, there was a catagory of prominent political science practitioners who cannot be pidgeon-holed as either belonging either to this or that particular school or ideological camp, people who excelled in independent thinking, quality scholarship, and in cases when theory and practice did intersect, they tried to clarify issues, shunning advocating or partisanship. I must admit that my interaction with local Enlish-speaking academic colleagues was limited and I mainly think of Afrikaans-speaking academics like Ben Roux, Mike Louw, Willem Kleynhans, Ben Vosloo, Jan Lombard (political economist) who stood out in this regard. They were of the second generation Political Scientists, coming after the older generation represented by, inter alia, Alfred Hoernle, EFW Gey van Pittius, JJN (Koos) Cloete, Herman Strauss, H G Stoker and AH Murray. At their time, political/philosophical thinking in Afrikaans universities was greatly influenced by German and Dutch political and theological philosophers, while the seminal thinkers from classical Greece and Rome as well as the Renaissance and Reformation periods constituted a major portion of the undergraduate carricula. Apart from the latter, the impact of particularly Max Weber, Dooyeweerd, Kuyper, Harold Laski, Brecht, Dahl and Hans Mogenthau (a German-American) particularly was particularly prominent. As far as the study of government/governance was concerned British political science held most of the sway, as is the case today. A shift from the continental European influence took place during the 1960s and 1970s when American political science started to dominate, particulsarly by way of 'new' theoretical thinking, finding its way into prescribed text books and curricula both in political science and international relations. At the time, the attraction of a 'value free' political science became a preferable pursuit among the younger generation of political scienctists (mainly at Universities of Stellenbosch, Pretoria and Rand Afrikaans University), with particular reference to 'behaviouralism', quantative analysis and empiricism, as 
well as the developmental/stability theories became an esssential part of the bill of fare. A 'South African political science' simply did not exist. Also, apart from the notable work of the Africa Institute under the leadership of Erich Leistner and Denis Venter, African studies hardly figured. What was important though from the point of view of the teaching and research of political science and international relations was that the new insights from the 1960 onward harbingered the emergence of what might be called Weberian 'pure scientists' of the 'third generation' academics, particularly Deon Geldenhuys, Murray Faure, Andre Louw, Andre Dupisani, Marie Muller, Maxi Schoeman, Koos van Wyk, Eric Wainwright and Gerhard Totemeier. Some of these names featured regularly in Politikon.

The picture would, however, never be complete without stressing the important role played by 'public intellectuals', particularly David Welsh, Ben Vosloo, Denis Worrall, Ben Roux, HW van der Merwe, Johan Degenaar, Jan Lombard and Dan Kriek, as well, par excellence, of very exceptional individuals like Van Wyk Louw (poet and playwright), Willem de Klerk (theologian) and Frederik Van Zyl Slabbert (sociologist). It was a debate about politics, but with an intedisciplinary character, by concerned South African intellectuals who were brave enough to test the mine field of local politics. And, indeed, they were in every sense visionary pioneers, creating an intense intellectual fermentation process, questioning the apartheid status quo, initiating the pathbreaking 'verligte' phenomenon in South Africa's political life, particularly during the turbulent 1980s. What they did was to start a veritable paradigmatic revolution, challenging the Verwoedian iron law of apartheid. As such, they were the main role players, the harbingers, preparing much of the way for political volte face by the Nationalist government and the national renewal and transformation of the 1990's. Being politically neutral or unatttached SAPSA and Politikon were only never really part of this important process.

Talking to the African National Congress (ANC) was strictly verboten by the nationalist government until FW de Klerk became president and saw the light. Shunning the consequences, these intellectuals took the risk upon themselves to start the debate with the ANC secretly in far-flung places, a debate which indeed changed the future of South Africa. Coupled with there concern about how to normalise the political process in the country, was how to structure a legitimate democracy in a plural, deeply divided society such as South Africa, relacing the old order. In the end, at the Codesa negotiations, lawyers and party politicians dominated, and not much came of their ideas or proposals based on consociational democracy and federalism (rather than a winner-take-all parliamentary democratic dispensation). Even so, the peacefull transformation and the new constitution that finally came about, given the complexity of the South African situation, was indeed something of a miracle.

All this confirms what John Maynard Keynes famously stated: "The ideas of economists and political philosophers, both when they are right and when they are wrong, are more powerful than is commonly understood. Indeed, the world is ruled by little else."

But lamentably so, there seems to be something of an intellectual lacuna in South Africa these days.The voice of contemporary political scientists in South Africa seldom, if ever, penetrates or impact on national decision-making or influence the public mood. Intellectual leadership (as well as political, no doubt) in the country is at an all-time low ebb and perhaps the time has come for more of our politcal scientists to leave their ensconsed ivory tower environments and do some stock- 
taking and think more about relevance in our state and society. While the formal teaching of political science has, no doubt, developed with leaps and bounds in the country, there is a glaring paucity as far as the critical participation of political scientists (with a few exceptions like paricularly Amanda Gouws, Chris Landsberg, and Steven Friedman) in the public debate is concerned. It is hard to think that esoteric detachment should prevail among political scientists in a volatile country beset with so many pressing and critical issues like South Africa. In some cases, we seem to have reached the point in the evolution of theoretical and empirical scholarship "when work about the work in the field eclipses work about the field. In the development of Marxism, for instance, writing about industrial conditions, class conflict, wages, and profits over time became secondary to writing about the history, varieties, contradictions and interpretations of Marxist thought on these subjects." ${ }^{11}$ The challenge to local policy makers and practitioners, it seems to me, is taken up mainly by economists, lawyers, the fourth estate and a handful of local generalist think tanks.

The collection of essays for this festival issue of Politikon, for practical reasons, does not reflect the total ambit of political science and international relations in South Africa. It confirms, however, that that as far as theorising and teaching are concerned the discipline has indeed flourished and is in good health, albeit, perhaps, not completely mature or 'originally African' as it should be.

Complacency is not a word that exists in the scientist's lexicon. To reach the higher plateau, there are still further and new challenges facing us as practising political scientists in South Africa if the goal of relevancy as role players as participants in shaping our paticular environment is to be met.

Gerrit Olivier

$8 / 9 / 2013$

\footnotetext{
${ }^{1}$ Myron Weiner and Samuel Huntington (Eds) (1987), Understanding Political Development (Little Brown, Boston), p3
} 